Institutional Report

\title{
Birbal Sahni Institute of Palaeosciences: An Overview of Recent Advances and Developments
}

SUNIL BAJPAI*

Birbal Sahni Institute of Palaeosciences, 53 University Road, Lucknow 226 007, India

(Received on 25 April 2016; Accepted on 25 June 2016)

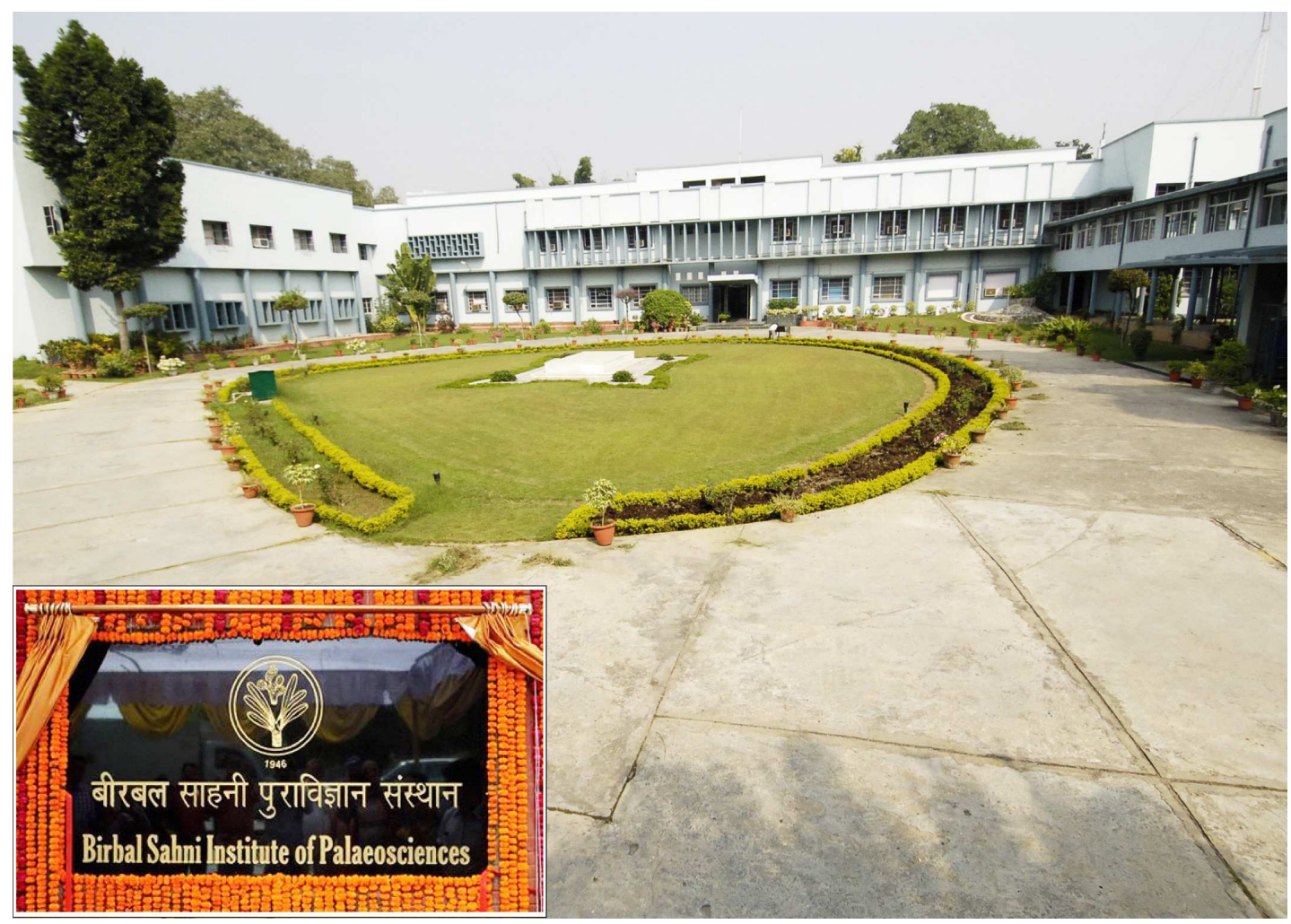

\section{Introduction}

The Birbal Sahni Institute of Palaeobotany was established in the year 1946 with the overall objective of deciphering the evolutionary history of plant kingdom through the study of fossil plants. The credit for this great accomplishment goes to Prof. Birbal Sahni himself, after whom this unique centre of research was named after his untimely demise. Earlier renowned Professor Sir Albert Charles Seward had initiated Late Prof. Sahni into the science of palaeobotany at Cambridge University and recognized the potential of the then young Sahni. Subsequently at one point, Prof. Seaward advised the Geological Survey of India to send the plant fossils in its collection to Birbal Sahni, then based at University of Lucknow, instead of sending them to the UK. Studies on plant fossils thus systematically began in India in 1921, and during the next quarter of a century, Sahni, besides studying the plant fossils, also explored the potential

\footnotetext{
*Author for Correspondence: E-mail:director@bsip.res.in
} 
application of palaeobotany to areas pertaining to the basic and applied aspects of botany and geology. Prof. Sahni's tireless efforts thus laid a firm foundation for studies on plant fossils in India, leading up to the establishment of the Institute of Palaeobotany at Lucknow in 1946. Since then, the institute has grown constantly and has continuously generated new data. Currently, research activities at the Institute include studies on plant fossils and associated micro-and macrofossils, past-climates, -environments and ecosystems, palaeobiogeography, biostratigraphy, geochemistry, fossil fuel exploration, palaeoethnobotany as well as and development of apppropriate analytical tools. To provide the necessary thrust on multidisciplinarity and an integrated approach within the overall framework of Earth System sciences, this institution was recently renamed Birbal Sahni Institute of Palaeosciences (BSIP). The recent induction of analytical facilities and scientists has enabled BSIP to delve deeper into multiple dimensions of palaeosciences. This contribution highlights some of the important scientific activities carried out during the period 2010-15 and discusses their importance in the understanding of biotic evolution, past ecosystems and climates.

Currently the basic mandate of BSIP is to carry out multidisciplinary research in palaeosciences pertaining to evolution of biotas, climates and ecosystems and, under this mandate, the main main thrust areas are:

1. Early life, contemporary environments and evidence from Indian Precambrian basins,

2. Phanerozoic terrestrial and coastal ecosystems: Biostratigraphical, palaeoenvironmental, palaeoecological and palaeogeographical aspects,

3. Marine micropalaeontology with a focus on high resolution biostratigraphy, sea level changes, palaeo-oceanographic and palaeoclimatic events,

4. Organic petrology including characterization of solid fossil fuels in terms of depositional setting and utilizational aspects,

5. Quaternary palaeoclimate reconstructions, vegetation dynamics and sea level changes,
6. Domestication of plants, early farming and ecosystem dynamics during Holocene and Anthropocene,

7. Geochronological and geochemical studies for high resolution dating, regional stratigraphic correlation, palaeoclimatic, tectonic and provenance studies,

8. India-Asia collision and Himalayan uplift and their signetures in palaeobotanical and associated biota in sediments of northwest Himalaya.

Numerous analytical facilities have been set up during the past three years. These include elemental stable isotope and organic geochemistry, (ICP-MS, IRMS, GC-MS), XRD, FE-SEM, CLSM with Raman Spectroscopy, luminescence dating and magnetostratigraphy. Apart from their own research project BSIP scientists help Oil India Ltd., ONGC, Coal India Ltd, Archaeological Survey of India in their studies involving micropalaeontogical and paleobotanical inputs.

\section{Highlights}

\section{Precambrian}

Carbonaceous fossils in the Precambrian sedimentary successions of India continue to provide important insights into the evolutionary history of early life ranging from single-celled prokaryotes to nucleated eukaryotic cells and multicellular life forms that appeared and evolved during the first three billion years of earth's history. Studies on these remains from India have led to a better understanding of the evolutionary pathways adopted by life forms during the Neoproterozoic Era (1000-541 Ma). All such remains have been investigated for their biogenicity, syngenecity and age because of possible uncertainities in distinguishing the true fossils from pseudofossils. Carbonaceous compression fossils from the various Precambrian basins of India were reviewed by Sharma et al. (2012). Sharma and Shukla (2012a) reported annulated compression/impression fossils from the Hulkal Formation of Bhima Basin of India $(\sim 750 \mathrm{Ma})$ and established the existence of PreEdiacara epi-benthic organisms. Elsewhere, the earliest multicellular, megascopic benthic algal life has been documented from the Ediacara and slightly older periods ( 635-541 Ma) and includes complex 
multicellular carbonaceous megascopic forms (seaweed) (Yuan et al., 2011, 2013). The older ages of carbonaceous fossils from the Bhima basin of India suggest that these forms survived the glaciation events before passing into the Ediacaran time.

Organic walled microfossils of eukaryotic affinity occur extensively in the silicified cherts and carbonaceous shale of Meso-Neoproterozoic Vindhyan, Chhattisgarh, Kurnool and Ediacaran sediments of Lesser Himalaya, India (Singh et al., 2011; Sharma and Shukla, 2012a,b; Shukla and Tiwari, 2014; Singh and Sharma, 2014). In a monograph by an Indo-Russian team, Sergeev et al. (2012) reviewed 50 genera and 90 species of fossil cyanobacteria using petrographic thin sections of different Proterozoic formations across the world. To date, this study provides the most exhaustive account of the morphology, palaeobiology, palaeoecology and geological history of cyanobacterial microfossils. Singh et al. (2011) reported an assemblage of cyanobacterial microfossils of endolithic habitats from the carbonate facies of the Bhander Group of the Vindhyan succession. In another important work, Sharma and Shukla (2012b) reported helically coiled microfossils of Obruchevella, a Vendian marker, from the Owk Shale of the Kurnool Group, which suggests an Ediacaran rather than a Mesoproterozoic age for this sequence. Babu and Singh (2013) and Babu et al. (2014) reported a diverse assemblage of Neoproterozoic chert permineralized microbiota from the carbonate facies of Raipur Group (Chhattisgarh Supergroup) and discussed its biostratigraphic significance. Furthermore, the oldest morphologically complex organic-walled eukaryotic microfossils have been reported from the latest Palaeoproterozoic-Early Mesoproterozoic Chitrakut Formation (>1600 Ma old) of the Vindhyan Supergroup (Singh and Sharma, 2014). This find predates the oldest record of eukaryotic fossils known from $\sim 1500 \mathrm{Ma}$ and takes the antiquity of eukaryotic microfossils farther back in deep time.

The Marwar Supergroup has also yielded varied fossils of Ediacaran to Cambrian age. Contributions from the BSIP have led to a better understanding of the biodiversity of the various Ediacaran to Cambrian lithounits of the Jodhpur Sandstone (Kumar and Ahmad, 2012; 2014; 2016). These finds include the non-vascular megaplant fossils (Kumar and Ahmad,
2016). From the Nagaur Group, trace fossils (Ahmad and Kumar, 2014) including burrows and scratch marks of arthropods have been described from the fine to medium grained sandstones (Ahmad and Kumar, 2014). These and associated finds have enriched our knowledge of the diversity of Ediacaran biosphere and have also helped refine the stratigraphic division of the Ediacara and Lower Cambrian intervals.

\section{Palaeozoic-Early Mesozoic}

Contributions from BSIP have a led to a significant refinement of the Gondwana biostratigraphy and the Gondwana biodiversity. Extensive megafloristic studies pertaining to evolutionary, palaeoecological and palaeoenvironmental aspects were conducted in the various Gondwana basins of India during. A comprehensive review on the morpho-taxonomy of Permian spores from the Indian Gondwana successions was published by Vijaya and Murthy, (2013). Another study on the thecamoebians from the Late Permian Gondwana sediments of peninsular India adds a new dimension to our knowledge of the Gondwana biodiversity (Farooqui et al., 2014). On the basis of shell morphology and morphometry, sixteen thecamoebian species have been recorded in this study. The study also elucidates the minimal morphological evolution in thecamoebians and their survival during the periods of mass extinction and stressful environmental conditions. The first record of fresh water diatom frustules along with the tests of thecamoebians recovered from Permian sediments ( $\pm 251-299 \mathrm{Ma})$ of Chamba basin, Himachal Pradesh and Godavari sub-basin, Andhra Pradesh, India has also been documented (Farooqui et al., 2015). This work provides evidence for the existence of diatoms prior to the Permian-Triassic boundary. In another interesting study, charcoal fragments in the deposits of Chintalapudi sub-basin of the Godavari graben provided evidence of palaeo-wildfires (Jha et al. 2014). Morphological characters of charcoal were also utilized in taphonomic interpretations (Mahesh et al., 2015a). In a similar contribution, palaeo-wildfires, as evidenced by the occurrence of tracheid fragments of charcoals with homogenized cell walls, were documented from the Late Permian Zewan Formation of Kashmir. NW Himalaya (Jasper et al., 2016).

Numerous naked, fossil spore tetrads assignable to Indotriradites, Microbaculispora and 
Microfoveolatispora were recently reported for the first time from the early Permian Lower Barakar Formation of Singrauli Coalfield, Son-Mahanadi Basin, Central India (Saxena et al., 2015). This study provides important data to test the hypothesis that the formation of tetrad spores is linked to extreme climatic conditions. Global records of such tetrad spores in the Ordovician-Lower Devonian, Early Permian, Permo-Triassic boundary and thereafter in the Early Triassic sediments, have been correlated with extreme cold (due to Ordovician - Silurian and CarboniferousPermian glaciations) and hot (due to Early Triassic Siberian volcanic activity) climatic conditions.

BSIP has an ambitious programme on polar studies, and its participation in India's Antarctic and Arctic expeditions has provided important results on palaeobiological and palaeoclimatic aspects. In an important study on the Permian-Triassic palynoflora from the Allan Hills, South Victoria Land, Antarctica (Ram Awatar et al., 2014), the Late Permian age of the Weller Formation was corroborated based on the similarity of its palynoassemblage to that of the Upper Stage-5 (Late Permian) of Australia. Also, the Lashly Formation was shown to be correlatable with the Aratrisporites parvispinosus Zone of Australia. A heterogeneous and well preserved assemblage of Triassic megafossils, belonging to pteridophytes and gymnosperms, was also described by these workers from the Lashly Formation of Allan hills. The assemblage is dominated by corystosperms and includes many species of the genus Dicroidium. Furthermore, it has been suggested that the persistence of green house conditions from the end of the Permian to the Triassic allowed the rich and diverse Dicroidium forests to develop in the polar regions of Antarctica (Chatterjee et al., 2013). This study indicates a much older origin of Dicroidium than previously suspected. Also, a comprehensive documentation of the Glossopteris flora from the Permian Weller Formation of Allan Hills, Antarctica has been shown to include well preserved pteridophytes, gymonosperms, and Equisetales (Tewari et al., 2015). The recorded flora shows close similarity with the Late Permian assemblages of India, South Africa and Australia. Gangamopteris, an index fossil of Early Permian formations of different Gondwana continents, has been shown to have an extended stratigraphic range in the Late Permian Weller Formation of Allan Hills (Tewari et al., 2015a).
A rich and well preserved Glossopteris-dominated plant fossil assemblage has also been described from the Barakar Formation in the coalfields of Makardhokra and Umrer, Wardha Basin, Maharashtra, India (Tewari et al., 2012). The flora exhibits several unique characteristics and is Artinskian to Kungurian in age. This study provides the first systematic documentation of the Glossopteris flora from the Barakar Formation of the Wardha Basin. Another study, pertaining to the Lower Gondwana plant fossils of Mohpani Coalfield of Satpura Gondwana Basin (Madhya Pradesh), revealed the dominance of Gangamopteris species over the Glossopteris species as well as the absence of Noeggerathiopsis, indicating floral affinities with the Lower Barakar flora of (Srivastava et al., 2012).

A comprehensive review of the megaflora, palynology and geological setting of the Talcher Basin of Orissa has also been published recently (Goswami and Singh, 2013). This study concludes that several groups of plants disappeared during the PermianTriassic interval (Lower Kamthi-Upper Kamthi) and that many new forerunners appeared in a step-wise manner in the Upper Kamthi Formation. The study also advocates the continued survival of plants, rather than a mass extinction, around the Permo-Triassic $(\mathrm{P} / \mathrm{T})$ boundary in the Talcher Basin. Another review study on the genus Euryphyllum incorporating morphology, cuticular aspects and the affinities suggested that asymmetry of the leaves that used to be an important character for generic distinction, cannot be considered as a distinguishing feature for this genus (Saxena et al., 2013). In another study, the utility of plant megafossils in correlation of coal seams in the Gondwana coalfields of India was discussed (Srivastava and Agnihotri, 2013).

In another recent contribution (Singh et al., 2013), the Carboniferous flora and associated depositional environments in two of the best plant fossil localities in the Pir Panjal Range of Kashmir Himalaya have been studied in detail for the first time. Some of the fine-grained, shallow marine deposits yielded fossil floras dominated by sub-arborescent taxa. Of these, the taxa Flabellofolium, Botrychiopsis, Annularia and Cordaites have been recorded for the first time from the Indian carboniferous. The assemblage is comparable to other Gondwanan floras assigned to the Paraca floral realm, and has been interpreted as 
evidence of relatively warm climatic conditions that existed prior to the onset of the Carboniferous-Permian ice age.

A recent study (Tewari et al., 2015b) deals with the palynological transition in the Permian-Triassic Boundary sequence of the famous Guryul Ravine Section, Kashmir Himalaya, India. The study revealed an impoverished latest Permian spore pollen assemblage in the uppermost Zewan Formation, a rich palynoassemblage from the basal Kunumuh Formation characteristic of the P-T transition zone, and a depleted Triassic assemblage from a horizon higher up in the Kunumuh Formation. The low spore pollen yields and the poor preservation of the recovered assemblage was attributed to the offshore marine depositional setting on the margin of the Neotethys ocean and the thermal alteration associated with the Cenozoic collision between India and Asia (Tewari et al., 2015b). A study on thecamoebians from the same section has confirmed their morphologic stability through the Phanerozoic, unaffected by one of the greatest mass extinction events (P-T) in earth's history (Singh et al., 2015).

Based on new collections, Cleal et al. (2016) recently made a critical assessment of the lycopsids reported from the Kashmir Himalaya. The material has been shown to belong to a single taxon and the variations have been attributed to variable growth rate during the life of the individual plants. Anew taxonomic name, Spondylodendron pranabii (Pal) comb. nov., was proposed for all previously reported and the new material from Kashmir. In another interesting study (Singh et al., 2016), some exceptionally well preserved, vertical (in situ) Vertebraria axes and the horizontally preserved allochthonous Glossopteris leaves have been described for the first time from the Raniganj Formation of Singrauli Coalfield, SonMahanadi Basin.

\section{Cretaceous-Neogene}

Tracing the early evolutionary history of angiosperms is an important area of research at BSIP. A collaborative study by BSIP on the Carnoconites seeds preserved in the early Cretaceous intertrappean cherts of Rajmahal Hills suggested angiosperm-like traits of the Indian Pentoxylon plant (Srivastava and Krassilov, 2012). In another collaborative work, the oldest record of a coryphoid palm (Sabalites dindoriensis) was reported from the late Cretaceous Deccan Intertrappean deposits of Central India. This find has opened a new window for understanding palm dispersal in the southern hemisphere since, according to the authors, coryphoid palms dispersed into India from Europe via Africa during the latest Cretaceous (Srivastava et al., 2014). Silicified plant tissues (phytoliths) have also been studied from late Cretaceous ( $\sim 65 \mathrm{Ma}$ ) dinosaur dung and associated sediments from a Deccan intertrappean locality in central India (Prasad et al., 2011). This study demonstrated the presence of wild rice phytoliths in the dinosaur dung and intertrappean sediments and suggested an early diversification of the grass family Poaceae, with possible origin of rice in India about 65 Ma.

In another study based on palynofacies and sedimentology, Prasad et al. (2013) have deciphered palaeoenvironmental conditions and facies architecture of the early Eocene Cambay Shale sequence at the Vastan Lignite Mine in the Cambay basin of western India. This study suggested that the Vastan lignite sequence was deposited in a low-energy coastal marsh-bay complex and that the lower part of this sequence, which possibly represents a Transgressive Systems Tract ( $3^{\text {rd }}$-order cycle), comprises four depositional facies representing open bay, restricted bay, creek and channel and coastal marsh.

The Paleocene-Eocene transition has long been known to be a period of extreme global warming. To trace the response of mangrove vegetation to the early Paleogene warming, the species diversity of the spinizonocolpites pollen Nypa across the PaleoceneEocene transition was studied from two paleoequatorial shallow marine stratigraphic sections in the east Khasi hills, South Shillong Plateau, Meghalaya (Srivastava and Prasad, 2015). The study showed higher diversity around the Paleocene-Eocene boundary in both sections, followed by a significant decline during the Eocene. The variation in species diversity and origination rate of the back mangrove palm genus Nypa during the Paleocene-Eocene transition is important in understanding the effect of global warming on mangrove vegetation in paleoequatorial regions.

Early Paleogene mammal faunas of India are of great importance in understanding the origin and 
early evolutionary history of different groups in the context of India-Asia collision, hyperthermal events, and biogeographic dispersal. A collaborative study (Cooper et al., 2014) on anthracobunids, a middle Eocene family of large ungulate mammals from South Asia demonstrated that this group, as well as the previously named family Cambaytheriidae, are stem perissodactyls. Analyses of stable isotopes and long bone geometry together indicated that most anthracobunids fed on land, but spent a considerable amount of time near water. An equally important recent find is the oldest South Asian tapiroid (Cambaylophus vastanensis) from the early Eocene ( 54-55 Ma) Cambay Shale at Vastan lignite mine, Gujarat. India (Kapur and Bajpai, 2015). This new taxon appears to be closely nested with the early Eocene (Bumbanian) tapiromorph Orientolophus from China and suggests a degree of terrestrial connectivity between the Indian Subcontinent and the Asian landmass Asia around the time of India-Asia collision, at or near the Paleocene-Eocene boundary.

Quantitative estimates of climatic parameters of the Indian subcontinent during pre- and post-IndiaAsia collision stages are of great interest. Collaborative investigations of the early Eocene ( $55-52 \mathrm{Ma}$ ) Gurha Lignite Mine section of Rajasthan yielded a diversity of fossil leaves, flowers, fruits and seeds (Shukla et $a l .$, 2014). CLAMP analysis of the recovered fossil leaves indicated cool equatorial $\left(\sim 10^{\circ} \mathrm{N}\right)$ temperatures and a monsoonal climate during the early Eocene. The study also suggested that the South Asian monsoon already existed during the initial stages of India-Asia collision.

Studies on organic petrology of the Indian lignites and coals are also conducted at BSIP (eg. Singh and Singh, 2008). Such studies deal with the estimation of microconstituents (macerals) in coals/lignites formed during the transformation of vegetal matter into coal/ lignite. The data on the type and amount of macerals (organic matter) and the degree of maturation (determined through vitrinite/huminite reflectance) of Indian coals/lignites have been variously interpreted in applied and academic research. A multidisciplinary approach involving palynology and palynofacies has been adopted in recent years to characterize and assess the depositional conditions of western Indian lignites. The variable values of tissue preservation and gelification indices and maceral composition of
Mangrol lignite (Cambay Basin) indicate fluctuating groundwater conditions and differences in the type of vegetation during the accumulation of peat (Singh et al., 2013). High amount of amorphous matter (Kerogen I) in shales resting above the lignite and the high content of liptinite macerals (resinite + liptodetrinite) in lignites suggested the potential of lignite-bearing sequence for generation of hydrocarbons. Integrated petrographical, palynological and organic geochemical investigations were carried out to evaluate the source vegetation, depositional history and hydrocarbon source potential of Matanomadh lignites of Kutch (Dutta et al., 2011). The study concluded that the angiosperm-dominated woody forest vegetation served as the source material for lignites deposited in tropical to sub-tropical climatic conditions in coastal areas close to the palaeoshoreline. High TOC and presence of mixed type II/ III kerogens suggested that the lignite-bearing sequence has the potential to generate both oil and gaseous hydrocarbons on maturation. Similar, integrated studies are continuing in other lignite deposits of Gujarat and Rajasthan.

The Late Oligocene was the last major warm interval in earth's history before progressive Neogene cooling to the present day 'icehouse'. A study by Kumar et al. (2012) on late Oligocene deltaic sediments from the Tirap coal mine, Assam, NE India carried out CLAMP analysis of 80 fossil leaf morphotypes and worked out a mean annual temperature (MAT) of $26.1 \pm 2.7^{\circ} \mathrm{C}$, a warm month mean temperature (WMMT) of $27.9^{\circ} \pm 3.3^{\circ} \mathrm{C}$ and a cold month mean temperature CMMT of $20.1 \pm 4.3^{\circ} \mathrm{C}$. Precipitation estimates revealed a marked annual variation in rainfall with a pattern similar to the Sunderbans area of the modern Ganges/Brahmaputra delta. This study suggested that the South Asian Monsoon, with an intensity similar to present-day, was already established by the late Oligocene. In another study on Oligocene megafloral remains (Srivastava and Mehrotra, 2014), the record of Bridelia (Phyllanthaceae) indicated that the genus evolved $\sim 25$ Ma in Northeast India and later migrated to Southeast Asia via Myanmar and to Africa via the Iranian Route. In a similar finding, the fossil leaf of Alphonsea (Family Annonaceae) from the Late Oligocene of Makum Coalfield, Assam also indicates that the genus evolved in India and later migrated to SE Asia (Srivastava and Mehrotra, 2013). In another study, 
11 petrified fossil woods belonging to seven families were described from the Tipam Group (Late MioceneEarly Pliocene), Mizoram (Tiwari et al., 2012). Using the Coexistence Approach, this study indicated the existence of a tropical warm and humid climate with MAT (mean annual temperature) of $26.1-27.7^{\circ} \mathrm{C}$, a mean temperature of the warmest month (WMT) of 25.4-28.1 C, a mean temperature of the coldest month (CMT) of $25.6-26^{\circ} \mathrm{C}$, and a mean annual precipitation (MAP) of 3180-3263 mm during late Miocene-early Pliocene in Mizoram. The climatic interpretations were considered congruent with anatomical features of the fossil taxa. The study also provided evidence of floral exchanges between India and southeast Asia.

\section{Quaternary}

Quaternary research forms the largest sphere of activity at BSIP, and a number of different proxies (microfossils including pollen, diatoms \& phytoliths; elemental, stable isotopic and organic geochemistry; environmental magnetism; geomorphology; mineralogy; palaeoethnobotany; C-14 and luminescence dating) in varied climatic settings and terrains are currently investigated. Investigations are also being carried out in Antarctica and the Arctic. Scientists from BSIP regularly participate in the cruises of International Ocean Discovery Programs.

Reconstruction of open basin lakes in the cold arid region of NW Himalaya (Ladakh) is of considerable importance in understanding the tectonicclimate interplay. Three major palaeolakes (17-13 ka, $14-5 \mathrm{ka}, 12-1 \mathrm{ka}$ ) have been studied recently in a 136 $\mathrm{km}$ stretch along the present Indus River valley (Nag and Phartiyal, 2015). Another study from the Tangtse Valley (Phartiyal et al., 2015) recorded deglaciation following the Last Glacial Maximum (LGM) and the Holocene warming, together with changing depositional regimes and varied sedimentary architecture comprising fluvial, lacustrine, colluvial, aeolian and flood sediments spanning past $48 \mathrm{ka}$. The study also found evidence of a sixth lake basin (nearly $40 \mathrm{~km}$ in length between 9 to $5 \mathrm{ka}$ ) on the western side of Pangong Tso in the present day Tangtse Valley. This palaeolake existed during the periods of high lake levels in Tibet, China.

Using pollen, magnetic susceptibility and carbon isotope proxies late Pleistocene climate variations in the Ziro valley of Arunachal Pradesh, NE India were studied (Bhattacharyya et al., 2014). The study revealed an increased intensity of SW monsoon from $\sim 43,000$ cal yr BP to 34,000 cal yr BP and a decline thereafter. Peak warm and humid phase occurred around 36,181 cal yr BP and 34,145 cal yr BP., Decline of monsoon during the LGM was inferred from a lower Quercus-Pinus Index. This study is important in understanding the climatic variations and possible teleconnections with the Himalaya and other parts of the world.

Dendrochronology is an important area of research at BSIP. A 422-year long tree-ring width chronology (spanning AD 1591-2012) from Picea smithiana in Khaptad National Park, western Nepalese Himalaya was recently developed in a collaborative study (Thapa et al., 2014). Seasonal correlation analysis revealed significant indirect relationship with spring temperatures leading to the reconstruction of March-May average temperature for the past 373 years (AD 1640-2012). The reconstruction was significant based on validation statistics commonly used in tree-ring based climate reconstruction. The temperature reconstruction identified several periods of warming and cooling. The reconstruction did not show a significant pattern of cooling during the Little Ice Age although a few cold episodes were recorded. The spring temperatures revealed relationship with the Sea Surface Temperature index over the equatorial Pacific Ocean, pointing to linkages with climatic variability on a global scale. In another study (Yadav et al. 2015), drought variability during the past $\sim 300$ years was studied in the Kumaun Himalaya, based on Standardized Precipitation Index (SPI) reconstructed using treering width chronologies of the Himalayan cedar. The study noted a link between the rabi crop failures and food scarcity in the Kumaun region with the drought years recorded in observational and reconstructed SPI7-May series. In the western Himalaya, Yadav and Bhutiyani (2013) used the tree-ring data of Himalayan cedar from a network of six moisturestressed sites to develop the November-April Snow Water Equivalent (SWE) extending back to A.D. 1460. In the Sikkim Himalaya, NE India, a mean late summer temperature reconstruction extending back to $\mathrm{AD} 1852$ was attempted with the tree ring-width chronology of larch (Larix griffithiana) (Yadava et al., 2015). 
To assess the mid-Holocene climatic fluctuations and their possible impact on the Harappan culture (Prasad et al., 2014), a multi-proxy study involving palynology, phytoliths, sedimentology, clay mineralogy, carbon isotope and magnetic mineralogy was conducted in lacustrine sediments from the sub-humid zone of Mainland Gujarat, in conjunction with archaeobotanical data. The study documented low lake level and dry climate during the period from $~ 5560$ to $\sim 4255$ cal yr BP, synchronous with the other lake records of western India. It was deciphered that the emergence of cultural complexity of Harappan civilization at the same time is an initial adaptation to the earliest phase of dry climate in this region and that the fall of the Harappan culture was probably linked to the excessive dry climate of the later phase of mid-Holocene ( 4200-4255 cal yr BP).

Recently, in a palaeoethnobotanical study dealing with climate-culture relationships, archaeological datasets on small-grained millets from the core and peripheral regions of the Indus/Harappan civilization were studied in relation to crop economy and cultural change (Pokharia et al., 2014). These authors evaluated the significance of the fossil grains of sorghum millet, little millet, finger millet, pearl millet and foxtail millet from various archeological sites from the Early (3000-2500 BC), Mature (2500-2000 BC), and the Late Harappan (2000-1400 BC) sites. The study demonstrated a significant role of millets in the Harappan agricultural system since the Early Harappan period. The shift towards drought-resistant millet crops in the peripheral region of the Indus/ Harappan civilization was interpreted as a cultural adaptation in response to the decline of SW monsoon during the late Holocene ( $\sim \mathrm{ka})$. Clearly, such adaptation strategies to persistent drought conditions in ancient civilizations provide a valuable perspective for possible strategic planning in the context of future climate changes.

The soils of the past, especially in the preQuaternary period, are of interest because of their value in deciphering ancient atmospheric $\mathrm{CO}_{2}$ concentrations. Stable isotopic composition of vascular plant biomarkers from the Ganga Plain paleosols formed between 80 and $20 \mathrm{ka}$ was studied recently (Agrawal et al., 2014). Carbon isotopic composition of $\mathrm{C} 32$ fatty acids suggested mixed $\mathrm{C}_{3}-\mathrm{C}_{4}$ plants over the Ganga Plain between 80-20 ka and a rapid doubling in $\mathrm{C}_{4}$ plant abundance around $45 \mathrm{ka}$. Comparison with a set of palaeoenvironmental proxies suggested that $\mathrm{C}_{4}$ plant expansion was closely controlled by hydrological conditions in the Ganga Plain. Overall, the study emphasized that the local palaeovegetation history of the Ganga Plain can be reconstructed using the stable carbon isotopic compositions of selected higher plant wax biomarkers and long chain fatty acids, especially C32.

Large Igneous Provinces (LIPs), which host mafic rocks spread over millions of square $\mathrm{km}$, have an important bearing on global sediment production and distribution. Recently, Sharma et al. (2013) conducted a case study on the texture, mineralogy, and chemical composition including REE of fine sand/ silt from the Mahi River of western India flowing in a tectonically active, semi-arid region and draining through the Deccan Traps, one of the largest LIPs in the world. This study showed about 70$75 \%$ contribution was from the Deccan Traps and 25-30\% contributions from the Archaean biotite-rich granitoids. The data are important in ascertaining the source characteristics of the alluvium and in evaluating comparative elemental mobility in relation to the role of climate in weathering processes.

Luminescence dating is one of the recently established laboratories at BSIP. A recently proposed mechanism seeks to understand the role of band-tail states of feldspars in infra-red luminescence production (Pagonis et al., 2014). Such studies are important in exploring more stable signals (i.e. less anomalous fading) and may eventually help date older sediments using feldspar (Morthekai et al., 2015). A major objective of ongoing efforts in the Luminescence Dating Lab at BSIP is to increase the overall accuracy and precision of ages derived from both quartz and feldspars.

\section{Concluding Remarks}

The newly renamed BSIP is now well placed to carry out multidisciplinary research in the vast field of palaeosciences including palaeobotany, palaeozoology, palaeoclimatology, palaeoenvironments, palaeobiogeography, palaeogeography, palaeoethnobotany, and numerous other related aspects. It is hoped that the new name will enthuse new energy and the pool of young scientists of BSIP, with nearly half of them below the age of 40 and over one-third of them women, will achieve the potential that the exciting field of palaeosciences offers. 


\section{Publications}

Agrawal S, Galy V, Sanyal P and Eglinton T (2014) $C_{4}$ plant expansion in the Ganga Plain during the last glacial cycle: Insights from isotopic composition of vascular plant biomarkers Organic Geochemistry 67 58-71

Ahmad S, Kumar S (2014) Trace fossil assemblages from the Nagaur Group, Western India Journal of the Palaeontological Society of India 59 231-246

Babu R and Singh VK (2013) Neoproterozoic Chert Permineralized silicified microbiota from the Carbonate Facies of Raipur Group, Chhattisgarh Basin, India: Their Biostratigraphic Significance Special Publication of the Geological Society of India 1 449-468

Babu R, Singh V K and Mehrotra NC (2014) Neoproterozoic Age Based on Microbiotas from the Raipur Group of Baradwar Sub-basin, Chhattisgarh Journal of the Geological Society of India $\mathbf{8 4} 442-448$

Bhattacharyya A, Mehrotra N, Shah S K, Basavaiah N, Chaudhary V and Singh I B (2014) Analysis of vegetation and climate change during Late Pleistocene from Ziro Valley, Arunachal Pradesh, Eastern Himalaya region Quaternary Science Review 101 111-123

Chatterjee S, Tewari R and Agnihotri D (2013) A Dicroidium flora from the Triassic of Allan Hills, South Victoria Land, Transantarctic Mountains, Antarctica. Alcheringa 37 209221

Cleal C J, Bhat G M, Singh K J, Dar A M, Saxena A and Chandra S (2016) Spondylodendron pranabii-the dominant lycopsid of the late Mississippian vegetation of the Kashmir Himalaya Alcheringa $\mathbf{4 0}$ (in press)

Cooper K L, Sears K E, Uygur A, Maier J, Baczkowski K S, Brosnahan M, Antczak D, Skidmore J A and Tabin C J (2014) Patterning and post-patterning modes of evolutionary digit loss in mammals Nature 511 41-45

Dutta S, Paul R P, Singh B D, Tripathi S K M, Singh A, Saraswati PK, Banerjee S and Mann U (2011) Petrology, palynology and organic geochemistry of Eocene lignite of Matanomadh, Kutch Basin, western India: Implications to depositional environment and hydrocarbon source potential International Journal of Coal Geology 85 91-102

Farooqui A, Aggarwal N and Jha N (2014) Arcellaceans (Thecamoebians) from Late Permian Gondwana sediments of Peninsular India Europian Journal of Protistology $\mathbf{5 0}$ 89-105

Farooqui A, Aggarwal N, Jha N and Phartiyal B (2015) Oldest Record of Freshwater Diatom Frustules in Tests of Permian thecamoebians: Faithfulness of Sedimentary Record International Journal of Current Microbiology and Applied
Sciences 4 472-485

Goswami S and Singh K J (2013) Floral biodiversity and geology of the Talcher Basin, Orissa, India during the PermianTriassic interval Geological Journal 48 39-56

Jasper A, Uhl D, Agnihotri D, Tewari R, Pandita S K, Benicio J R W, Pires E F, Augusto Stock Da Rosa A, Bhat G D and Pillai S S K (2016) Evidence of wildfires in the Late Permian (Lopingian) Zewan Formation of Kashmir, India Current Science 110 419-423

Jha N, Sabina PK, Aggarwal N and Mahesh S (2014) Late Permian Palynology and depositional environment of Chintalapudi sub basin, Pranhita-Godavari basin, Andhra Pradesh, India Journal of Asian Earth Sciences 79 382-399

Jha N, Saleem M and Aggarwal N (2013) Palynological dating of Lower Gondwana sediments in Gundala area, Godavari Graben, Andhra Pradesh, India Geophytology 42 85-92

Kapur V V and Bajpai S (2015) Oldest South Asian tapiromorph (Perissodactyla, Mammalia) from the Cambay Shale Formation, western India, with comments on its phylogenetic position and biogeographic implications Palaeobotanist 64 95-103

Kumar S and Ahmad S (2014) Microbially induced sedimentary structures (MISS) from the Ediacaran Jodhpur Sandstone, Marwar Supergroup, western Rajasthan Journal of Asian Earth Sciences 91 352-361

Kumar S and Ahmad S (2016) Earliest record of creeping mode of growth in megascopic plants: example from the Late Neoproterozoic Jodhpur Sandstone, Marwar Supergroup, western Rajasthan, India Journal of the Palaeontological Society of India (accepted)

Kumar S and Ahmad S (2015) Problematic structures from the Ediacaran Jodhpur Sandstone, Rajasthan, India and their possible affinity Journal of the Palaeontological Society of India $\mathbf{6 0} 21-26$

Mahesh S, Murthy S, Chakraborty B and Roy M D (2015a) Fossil Charcoal as Palaeofire Indicators: Taphonomy and Morphology of Charcoal Remains in Sub-Surface Gondwana Sediments of South Karanpura Coalfield Journal of the Geological Society of India 85 567-576

Mahesh S, Murthy S, Singh V P and Roy J S (2015b) Thermally altered coals from bore core EBM-1, East Bokaro coal field, Damodar Valley, India: A petrographic inference Journal of the Geological Society of India $\mathbf{8 6} 535-546$

Mahesh S, Murthy S, Sabina K P, Saran S and Singh V P (2016) Organic matter characterization of carbonaceous shales from Raniganj coalfields and its implications on depositional condition: A palynofacies and petrographic overview Journal of the Geological Society of India 87 132-144 
Morthekai P, Chauhan P R, Jain M, Shukla A D, Krishnan K, Sant D A, Patnaik R, Reddy D V and Singhvi A K, (2015) Thermally re-distributed IRSL (RD-IRSL): A new possibility of dating sediments near B/M boundary Quaternary Geochronology 30 154-160

Murthy S, Ram-Awatar and Gautam S (2014a) Palynostratigraphy of Permian succession in the MandRaigarh Coalfield, Chhattisgarh, India and phytogeographical provincialism Journal of Earth System Science 123 1879-1893

Murthy S, Sabina P K and Bernardes-de-Oliveira M E C (2015) Latest Permian palynomorphs from Jharia Coalfield, Damodar Basin, India and their potential for biostratigraphic correlation Revue de Micropaléontologie 58 167-184

Murthy S, Tripathi A, Chakraborti B and Singh U P (2014b) Palynostratigraphy of Permian succession from Binja Block, South Karanpura Coalfield, Jharkhand, India Journal of Earth System Science 123 1895-1906

Murthy S, Vijaya and Vethanayagam S M (2013) Palynostratigraphy of Permian succession in the Pench valley coalfield, Satpura basin, Madhya Pradesh, India Journal of the Palaeontological Society of India 58 241250

Nag D and Phartiyal B (2015) Climatic variations and geomorphology of the Indus River valley, between Nimo and Batalik, Ladakh (NW Trans Himalayas) during Late Quaternary Quaternary International 371 87-101

Pagonis V, Morthekai P and Kitis G (2014) Kinetic analysis of thermoluminescence glow curves, In feldspar: evidence for a continuous distribution of energies Geochronometria 41 168-177

Parcha S K and Pandey S (2011) Ichnofossils and their significance in the Cambrian successions of the Parahio valley in the Spiti Basin, Tethys Himalaya, India Journal of Asian Earth Sciences 42 1097-1116

Phartiyal B, Singh R and Kothyari G C (2015) Late-Quaternary geomorphic scenario due to changing depositional regimes in the Tangtse Valley, Trans-Himalaya, NW India Palaeogeography, Palaeoclimatology, Palaeoecology 422 11-24

Pokharia A K, Kharakwal J S and Srivastava A (2014) Archaeobotanical evidence of millets in the Indian subcontinent with some observations on their role in the Indus civilization Journal of Archaeological Sciences $\mathbf{4 2}$ $442-455$

Prasad V, Farooqui A, Sharma A, Phartiyal B, Chakraborty S, Bhandari S, Raj R and Singh A (2014) Mid-late Holocene monsoonal variations from mainland Gujarat, India: A multi-proxy study for evaluating climate culture relationship Palaeogeography Palaeoclimatology Palaeoecology 397 38-51

Prasad V, Strömberg C A E, Leaché A D, Samant B, Patnaik R, Tang L, Mohabey D M, Ge S and Sahni A (2011) Late Cretaceous origin of the rice tribe provides evidence for early diversification in Poaceae Nature Communication $\mathbf{2}$ $1-9$

Ram-Awatar, Tewari R, Agnihotri D, Chatterjee S, Pillai S S K and Meena K L (2014) Late Permian and Triassic palynomorphs from the Allan Hills, central Transantarctic Mountains, South Victoria Land, Antarctica Current Science 106 988-996

Sabina P K and Jha N (2014) Upper Cisuralian palynology and palaeoclimate of Manuguru area Godavari basin, India and their global correlation Journal of Earth System Science 123 1681-1692

Saxena A, Singh K J and Goswami S (2013) The Genus Euryphyllum Feistmantel Revisited - Occurrence and Diversity in Indian Gondwana Palaeobotanist 62 187-198

Saxena A, Singh K J, Murthy S, Chandra S and Goswami S (2015) Spore tetrads - ?Indicators of intense climatic regimes-A case study from Early Permian of Singrauli Coalfield, Son-Mahanadi Basin, India Geological Magazine doi:10.1017/S0016756815000382

Sergeev V N, Sharma M and Shukla Y (2012) Proterozoic Fossil Cyanobacteria. Palaeobotanist 61 189-358

Sharma A, Sensarma S, Kumar K, Khanna P P and Saini N K (2013) Mineralogy and geochemistry of the Mahi River sediments in tectonically active western India: Implications for Deccan large igneous province source, weathering and mobility of elements in a semi-arid climate Geochimica et Cosmochimica Acta 104 63-83

Sharma M and Shukla Y (2012) Megascopic carbonaceous compression fossils from the Neoproterozoic Bhima Basin, Karnataka, South India Geological Society, London 360 277-293

Sharma M and Shukla Y (2012b) Occurrence of helically coiled microfossil Obruchevella in the Owk Shale of the Kurnool Group and its significance Journal of Earth System Science $121755-768$

Sharma M, Kumar S, Tiwari M, Shukla Y, Pandey S K, Srivastava P, Banerjee S (2012) Palaeobiological Constraints and the Precambrian Biosphere: Indian Evidence Proceedings Indian National Science Academy 78 407-422

Shukla A, Mehrotra R C, Spicer R A, Spicer T E V and Kumar M (2014) Cool equatorial terrestrial temperatures and the South Asian monsoon in the Early Eocene: Evidence from 
the Gurha Mine, Rajasthan, India Palaeogeography Palaeoclimatology Palaeoecology 412 187-198

Singh A and Singh B D (2008b) Progenitors of hydrocarbon in Indian coals and lignites and their significance Geological Society of India Memoir 71 117-133

Singh A, Mahesh S, Singh H, Tripathi S K M and Singh B D (2013) Characterization of Mangrol lignite (Gujarat), India: Petrography, palynology, and palynofacies International Journal of Coal Geology 120 82-94

Singh K J and Saxena A (2015) End Permian (Lopingian) floral diversity in Singrauli coalfield: Evidences from Jingurdah colliery, Son-Mahanadi basin, India Journal of the Palaeontological Society of India 60 97-112

Singh K J, Saxena A and Goswami S (2016) In-situ occurrence of Vertebraria roots in the Raniganj Formation of Singrauli Coalfield and its palaeoecological significance Current Science 110 299-301

Singh K J, Singh R, Cleal C J, Saxena A and Chandra S (2013) Carboniferous floras in siliciclastic rocks of Kashmir Himalaya, India and the evolutionary history of the Tethyan Basin Geological Magazine 150 577-601

Singh V, Pandita S K, Tewari R, van Hengstum P J, Pillai S S K, Agnihotri D, Kumar K and Bhat, GD (2015) Thecamoebians (Testate Amoebae) Straddling the PermianTriassic Boundary in the Guryul Ravine Section, India: Evolutionary and Palaeoecological Implications PLOS ONE 10 e0135593

Singh V K and Sharma M (2014) Morphologically Complex Organic-Walled Microfossils (OWM) from the Late Palaeoproterozoic-Early Mesoproterozoic Chitrakut Formation, Vindhyan Supergroup, Central India and their implications on the antiquity of eukaryotes Journal of the Palaeontological Society of India 59 89-102

Singh V K, Babu R and Shukla M (2011) Heterolithic prokeryotes from the coated grains bearing carbonate facies of Bhander Group, Madhya Pradesh, India Journal of Applied Biosciences 37: 80-90

Srivastava A K and Agnihotri D (2013) Coal seam correlation in an Indian Gondwana Coalfield International Journal of Coal Geology 113 88-96

Srivastava A K, Saxena A and Agnihotri D (2012) Morphological and Stratigraphical significance of Lower Gondwana plant fossils of Mohpani Coalfield, Satpura Gondwana Basin, Madhya Pradesh Journal of Geological Society of India $\mathbf{8 0}$ 676-684

Srivastava G and Mehrotra R C (2013) First Fossil Record of Alphonsea Hk. f. \& T. (Annonaceae) from the Late Oligocene Sediments of Assam, India and Comments on
Its Phytogeography PLos One 8 1-6

Srivastava G and Mehrotra R C (2014) Phytogeographical implication of Bridelia Will. (Phyllanthaceae) fossil leaf from the late Oligocene of India PLos One doi: 10.1371/ journal.pone.o111140

Srivastava G, Mehrotra R C and Bauer H (2013) Palm leaves from the Late Oligocene sediments of Makum Coalfield, Assam, India Journal of Earth System Sciences 121747 754

Srivastava J and Prasad V (2015) Effect of global warming on diversity pattern in Nypa mangroves across PaleoceneEocene transition in the paleo-equatorial region of the Indian sub-continent. Palaeogeography Palaeoclimatology Palaeoecology 429 1-12

Srivastava R and Krassilov V A (2012) Revision of Early Cretaceous angiosperm remains from the Rajmahal Basin, India, with notes on the palaeoecology of the Pentoxylon plant Cretaceous Research 33 66-71

Srivastava R, Srivastava G and Dilcher D L (2014) Coryphoid Palm Leaf Fossils from the Maastrichtian-Danian of Central India with Remarks on Phytogeography of the Coryphoideae (Arecaceae) PLos One 9 1-10

Tewari R, Chatterjee S, Agnihotri D and Pandita S K (2015) Glossopteris flora in the Permian Weller Formation of Allan Hills, South Victoria Land, Antarctica: Implications for paleogeography, paleoclimatology and biostratigraphic correlation Gondwana Research 28 905-932

Tewari R, Pandita S K, Agnihotri D, Pillai S S K and BernardesDe-Oliveira M E C (2012) An Early Permian Glossopteris flora from the Umrer Coalfield, Wardha Basin, Maharashtra, India Alchering a 36 355-371

Tewari R, Ram-Awatar, Pandita S K, McLoughlin S, Agnihotri D, Pillai S S K, Singh V, Kumar K and Bhat G D (2015) The Permian-Triassic palynological transition in the Guryul Ravine Section, Kashmir, India: implications for Tethyan-Gondwanan correlations Earth Science Reviews 149 53-66

Thapa U K, Shah S K, Gaire N P and Bhuju D R (2014) Spring temperatures in the far-western Nepal Himalaya since AD 1640 reconstructed from Picea smithiana tree-ring widths Climate Dynamics 45 2069-2081

Tiwari M, Parcha S K, Shukla R and Joshi H (2013) Ichnology of early Cambrian Tal Group, Mussoorie Syncline, Lesser Himalaya, India Journal of Earth System Science 122 14671475

Tiwari R P, Mehrotra R C, Srivastava G and Shukla A (2012) The vegetation and climate of a Neogene petrified wood forest of Mizoram, India Journal of Asian Earth Sciences 61 
$143-165$

Vijya and Murthy S (2013) Permian spores from the Gondwana Succession in India Palaeobotanist 62 71-121

Wang Y, Du W, Komiya T, Wang X L and Wang Y (2015b) Macroorganism paleoecosystems during the middle-late Ediacaran Period in the Yangtze Block, South China Paleontological Research 19237-250

Wang Y, Wang Ye, Du W and Wang X (2015a) The Ediacara macroalgae Zhongbaodaophyton Chen et al., from south China Alcheringa 39 377-387

Yadav R R and Bhutiyani M R (2013) Tree-ring-based snowfall record for cold arid western Himalaya, India since A.D. 1460 Journal of Geophysical Research: Atmospheres 118 7516-7522
Yadav R R, Misra K G, Yadava A K, Kotlia B S and Misra S (2015) Tree-ring footprints of drought variability in last 300 years over Kumaun Himalaya, India and its relationship with crop productivity Quaternary Science Reviews 117 113-123

Yadava A K, Yadav R R, Misra K G, Singh J and Singh D (2015) Tree ring evidence of late summer warming in Sikkim, northeast India Quaternary International 371 175-180

Yuan X, Chen Z, Xiao S, Wan B, Guan C, Wang W, Zhou C and Hua H (2013) The Lantian biota: A new window onto the origin and early evolution of multicellular organisms Chinese Science Bulletin 58 701-707

Yuan X, Chen Z, Xiao S, Zhoua C and Hua H (2011) An early Ediacaran assemblage of macroscopic and morphologically differentiated eukaryotes Nature 470 390-393. 